\title{
The influence of river discharge on the thawing of sea ice, Mackenzie River Delta: albedo and temperature analyses
}

\author{
K. G. DEAN, W. J. STRINGER, K. AHLNÄS, C. SEARCY \& T. WEINGARTNER
}

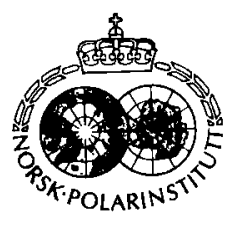

\begin{abstract}
Dean, K. G., Stringer, W. J., Ahlnäs, K., Searcy, C. \& Weingartner, T. 1994: The influence of river discharge on the thawing of sea ice, Mackenzic River Delta: albedo and temperature analyses. Polar Research 13, 83-94.

Multi-temporal satellite images, field observations and field measurements were used to investigate the mechanisms by which sea ice melts offshore from the Mackenzie River Delta. Satellite data recorded between April and August 1986 were corrected to a map projection and calibrated such that albedo and temperature values could be compared. Three stages in the melting of sea ice were identified: flooding (overflows), insolation and melting by warm river water. The albedo values of overflows were as much as $1 / 7$ that of ice values while the albedo of ice decreased by $1 / 3$ over the summer. Approximately two weeks after the overflows develop, sea surface temperatures rise as the river-discharge peaks and becomes the dominant source of energy. By this process, ice removal in the delta regime is initiated two months earlier than adjacent coasts with minimal runoff. However, the net result is only a two-week acceleration of ice removal in the delta region.
\end{abstract}

K. G. Dean, W. J. Stringer, K. Ahlnäs and C. Searcy, Geophysical Institute, University of Alaska Fairbanks, Fairbanks Alaska 99775-0800 U.S.A.; T. Weingartner, Institute of Marine Sciences, University of Alaska Fairbanks, Fairbanks Alaska 99775-1080, U.S.A.

\section{Introduction}

The purpose of this study was to investigate the processes by which arctic rivers influence the melting of sea ice during spring break-up. The longrange goal of the project was to understand how climate change, such as a global warming, would affect river discharge, and influence the timing and extent of the spring melt of sea ice. Changes in these sea ice parameters can affect the temperature of the Arctic Ocean and precipitation in arctic regions.

The thawing of rivers in the western Arctic occurs in late spring when sea ice is still largely continuous, extending from the North American to the Siberian coast, interrupted only by relatively narrow leads. The melting of arctic rivers begins in the headwaters and progresses downstream. The increasing river discharge and snow melt from surrounding terrain flood the sea ice in coastal areas (Matthews \& Stringer 1984). These over-ice-floods are referred to as "overflows" in this paper. As spring progresses, the relatively warm and fresh riverine water transports an increasing amount of heat from the terrestrial environment to the marine environment, initiating the melting of sea ice. This heat transport results in areas of open water offshore from river estuaries before any significant melting of sea ice occurs elsewhere along the coast. The rivers also transport sediments which are deposited on the sea ice. These deposited sediments decrease the sea ice albedo and hence increase solar absorption and accelerate the melting of the sea ice. The fluvial transport of terrestrial heat and the reduction of sea ice albedo are the dominant mechanisms for initiating the melting of sea ice.

Satellite imagery provides a repetitive, synoptic view of marine and terrestrial environments and an instantaneous view of dynamic hydrologic environments. The data also provide quantitative information on surface temperatures and albedo. Data from the Advanced Very High Resolution Radiometer (AVHRR) and Landsat TM sensors were used in this study. The AVHRR data were the primary source of information due to their high temporal resolution. This sensor records data twice daily with a $2200 \mathrm{~km}$ swath width at $1 \mathrm{~km}$ resolution. Data are collected in visible, reflected infrared and thermal infrared wavelengths. 


\section{Background}

The area offshore from the Mackenzie River Delta was selected as the initial study site (Fig. 1). The Mackenzie River is one of the primary sources of fresh water for the Arctic Basin supplying about $380 \mathrm{~km}^{3} / \mathrm{yr}$ (UNESCO 1978) to the Beaufort Sea and is the largest single source of sediment for the Beaufort Sea (Milliman \& Meade 1983). Mean monthly stream flow ranges from less than $5,000 \mathrm{~m}^{3} / \mathrm{s}$ during winter months to over $25,000 \mathrm{~m}^{3} / \mathrm{s}$ at peak discharge in June measured at Arctic Red River (Water Survey of Canada 10LCO14, 1986). The average rise in water level at the time of the spring peak discharge is approximately $5.5 \mathrm{~m}$ measured at Inuvik (Marsh \& Hey 1989).

Long-term surface circulation in the Beaufort Sea is dominated by the anticyclonic Beaufort Gyre (Newton 1973), an eastward flowing undercurrent seaward of the $50 \mathrm{~m}$ isobath (Aagaard 1984), and eastward flowing surface currents along the Alaskan and Canadian coasts during the summer (Matthews 1981). On the Mackenzie shelf, water mass structure and boundaries are complex with a variety of temperature, salinity and turbidity fronts that co-exist at any given time (Carmack et al. 1989). Sources of water on the Mackenzie shelf have been quantified using the distribution of $\delta^{18} \mathrm{O}$, salinity, temperature and nutrients (Macdonald et al. 1989).
The Mackenzie River empties into the Beaufort Sea which, in the vicinity of the delta, has an ice cover typically from November to June, or over $60 \%$ of the time. From near the coast to approximately $40 \mathrm{~km}$ offshore, water freezes annually forming ice that is stationary with respect to the coast and referred to as fast ice. Seaward of this zone lies ice that is highly dynamic and referred to as pack ice (WMO 1970). When the pack ice offshore from the Mackenzie River Delta moves away from the stationary fast ice it exposes sea water forming a lead and polynya system often referred to as the Cape Bathurst Polynya (Stirling $\&$ Cleator 1981). When the pack ice converges, the ice is deformed forming ridges (WMO 1970). The ridges form the fast ice near the fast/pack ice boundary parallel to the coast. Topographic relief is formed both above (ridges) and below (keels) sea level. The keels, which average 4.5 times deeper than the ridge above is high (Kovacs \& Mellor 1974), become dams trapping fresh Mackenzie River water on the shoreward size (Macdonald \& Carmack 1991).

\section{Methods}

\section{Satellite images}

Advanced Very High Resolution Radiometer (AVHRR) images recorded between 1978 and

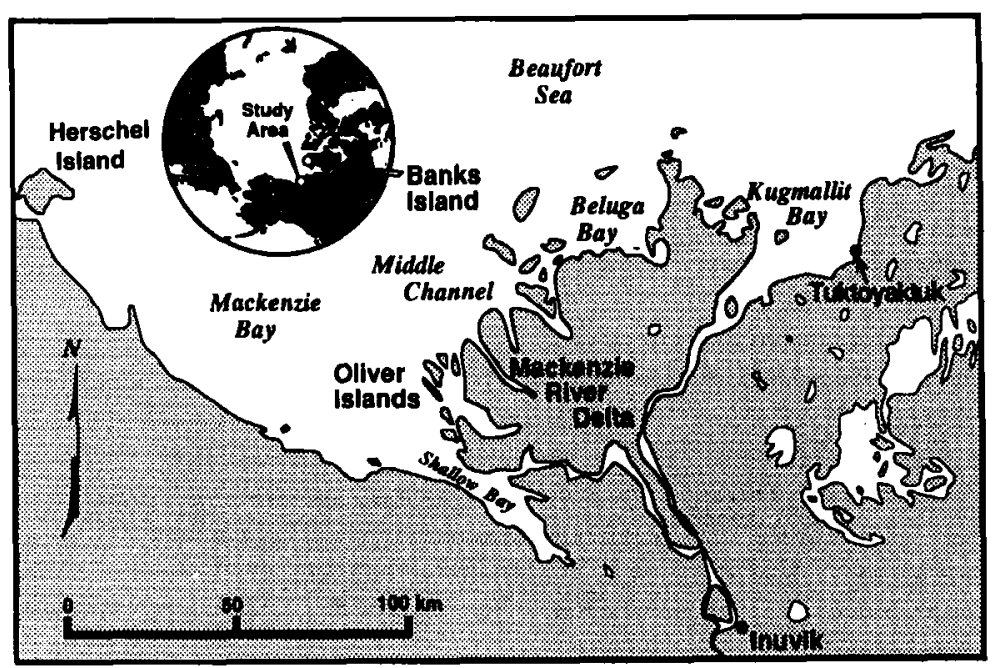

Fig. 1. Location of study area, offshore from the Mackenzie River Delta. 
1988 were reviewed to identify the year with the largest number of low cloud-cover images showing river and sea interactions. This search revealed 1986 as the year with the most favorable cloud conditions. Interannular analyses of sea ice patterns (Morris 1993) and annual river discharge records from the Water Survey Canada do not indicate that 1986 was an unusual year, and thus our results should be representative of conditions in this area.

Thirty-one images recorded between 25 May and 16 August having low cloud-cover in the vicinity of the delta showed the temporal variability of the thaw process. Fifteen of the thirtyone images were selected for digital processing. Nine of the digitally processed images are discussed in this paper (Table 1). Only digital tapes from the NOAA 9 satellite that recorded data at approximately 2200 UT were purchased for radiometric consistency. Also, two AVHRR were acquired for the spring of 1991, coinciding with field observations.

The satellite data have been processed to provide quantitative measurements and qualitative interpretations. The AVHRR data were subsectioned, geometrically corrected and radiometrically calibrated using modules in the Land Analysis System (LAS) image processing software. These analyses were consistently applied to each image such that intra-image comparisons could be made. Land was masked on these data and a digital coastline was merged with the images to help differentiate land and marine features and to provide geographic reference.
Albedo and temperature values were derived based on procedures described by NOAA (Kidwell 1991; Planet 1988), using an image processing software module called HRPTCAL in the LAS program. The following discussion is a summary of unpublished data (personal comm. Dr. Shusun Li, Geophysical Institute, Univ of Alaska).

Calibrated albedo values are generated using the AVHRR visible wavelength bands, channels 1 and 2 . The calibration procedure assumes a linear relationship:

$\alpha=\mathrm{MX}+\mathrm{I}$

where $\alpha$ is the albedo, $\mathrm{X}$ is the count level of the channel, $M$ and $I$ are the channel slope and intercept obtained from regression.

With certain options selected in HRPTCAL, the albedo $(\propto)$ is defined as:

$\alpha=\frac{\pi \mathrm{Lw}}{\mathrm{F} \cos \beta} \times 100 \%$

where $\mathrm{F}$ is the integrated solar spectral irradiance weighted by the spectral response function of the channel, $w$ is the equivalent width of the spectral response function of the channel, $\beta$ is the solar incidence angle, and $L$ is the space-measured, band-averaged, spectral radiance. Both $F$ and $L$ are measured at the top of the atmosphere, where $F$ is measured perpendicular to the solar beam.

Albedo values, generated by this procedure are space-measured, apparent spectral albedos, since the options selected in HRPTCAL did not

Table 1. Date and orbit number of satellite images digitally processed to analyze the effects of Mackenzie River discharge on sea ice.

\begin{tabular}{|c|c|c|}
\hline Date & Orbit \# & Comments \\
\hline 17 April 1986 & N9-6933 & No overflows observed. Ice adjacent to shore is warmer. \\
\hline 25 May 1986 & N9-7469 & $\begin{array}{l}\text { First overflows (four) observed immediately offshore from western discharge } \\
\text { channels. }\end{array}$ \\
\hline 4 June 1986 & N9-7610 & Five overflows observed (may include open water) with temperatures above zero. \\
\hline 11 June 1986 & N9.7709 & Notch in the ice edge first appear at the western end of the lead. \\
\hline 14 June 1986 & N9-7751 & $\begin{array}{l}\text { Western overflows coalescing and overflows appear in east channel. Overflows and } \\
\text { open water are warming. }\end{array}$ \\
\hline 3 July 1986 & N9-8019 & Western fast ice has melted. \\
\hline 5 July 1986 & N9-8047 & Remaining fast ice has melted and warm water at shore is coalescing. \\
\hline 12 July 1986 & N9-8146 & $\begin{array}{l}\text { Notch in the western ice edge is pronounced. Warm water seaward advancing front } \\
70 \mathrm{~km} \text { offshore. }\end{array}$ \\
\hline 16 Aug. 1986 & N9-8640 & $\begin{array}{l}\text { Water discharged by Mackenzie River is highly turbid and extends } 300 \mathrm{~km} \text { to the } \\
\text { west. }\end{array}$ \\
\hline
\end{tabular}


account for atmospheric effects and sun angle. A surface spectral albedo value can be obtained from $\propto$ by taking solar incident angle into account, and relating the surface albedo with the $\propto$ value from an atmospheric model and the incident and viewing geometry. The estimated accuracy using the above procedure is $+/-5 \%$ under clear-sky conditions in the Arctic if these factors are not taken into account.

Temperature values are derived from the oritical relationships between temperature and radiance based on the Planck function. The conversion of digital numbers (DN's) of surface features to band averaged radiance values, is achieved by using the calibration equation:

$B_{k}=M_{k} X_{k}+I_{k}$

where $\mathbf{M}_{\mathbf{k}}$ is the conversion slope for channel $\mathbf{k}$, $I_{k}$ is the channel intercept, $X_{k}$ is the reading at channel $k$. The $M_{k}$ and $I_{k}$ value are calculated for each channel using internal calibration sources and space spectral radiance values. The band averaged radiance is then converted to brightness temperature using the inverse of the Planck equation:

$$
T_{B, k}=\frac{C_{2} \vec{v}_{k}}{\ln \left(1+\frac{C_{1} \vec{v}_{k}^{3}}{B_{k}}\right)}
$$

where $\vec{v}_{k}$ is the central wave number for channel $\mathrm{k}$, and $\mathrm{C}_{1}$ and $\mathrm{C}_{2}$ are constants $1.1910659 \times$ $10^{-5} \mathrm{~mW} /\left(\mathrm{m}^{2} \mathrm{sr} \mathrm{cm}^{-4}\right)$ and $1.438833^{\circ} \mathrm{K} / \mathrm{cm}^{-1}$, respectively. $\vec{v}_{k}$ values are temperature ranges for each AVHRR channel derived from look-up tables (Planet 1988).

The algorithm for temperature derivation only produces the calibrated space-measured brightness temperature of an object averaged over the pixel. This algorithm does not directly give the kinetic ground temperature, since neither atmospheric corrections nor spectral emissivity of surface features are taken into account. The theoretical accuracy is $\sim 0.1^{\circ} \mathrm{C}$ if the atmosphere and emissivity are taken into account and perhaps $0.5^{\circ} \mathrm{C}$ under favorable conditions in the Arctic if these factors are not taken into account.

In our analysis albedo and temperature values within single and multiple images were compared. We assume that relative analyses within a single image and over limited areas (approximately
$500 \times 500 \mathrm{~km}$ ) are valid to $0.1^{\circ} \mathrm{C}$ and $0.5 \%$ albedo. Inter-image comparisons are assumed to be valid to $0.5^{\circ} \mathrm{C}$ and $5 \%$ albedo.

The images were analyzed using digital number (DN) level slicing techniques and the formation of color composite images. Colors were assigned to albedo and temperature ranges to form the level "slices". These slices were applied to the visible band (band 1) and thermal infrared band (band 4) data. A standardized temperature range and color assignment was developed for the thermal data but not for the optical data due to the magnitudes of their DN ranges. Custom slices were also developed. Color composites were formed using bands 1,2 and 4 for qualitative assessment of cloud cover, sea ice and overflow conditions.

Radiometric and spatial trends between scenes were compared. Variations in albedo and temperature in fast ice, pack ice, overflows and sea surface temperatures (SST's) were analyzed as a function of time, and their areal extents were qualitatively assessed on each image.

\section{Field observations}

The purpose of the field program was to investigate marine conditions in coastal regions offshore from the river delta and to compare these observations to the satellite images. Surface and sub-surface measurements were acquired in an attempt to estimate the affect of subaerial and submarine processes.

Field data were collected in May 1991 and compared with satellite data acquired during the same period and with data from the 1986 images. Stream gage records (Water Survey Canada) and a multi-year analysis of sea ice patterns (Morris 1993) show consistent recurring conditions, indicating that in this case it may be possible to draw some conclusions by comparing data from different years. The operation was based at the Polar Continental Shelf Project (PCPs) camp at Tuktoyaktuk, Northwest Territory, Canada.

The field program consisted of aerial observations and measurements of fast ice, sub-ice and open water marine conditions, and overflows adjacent to the coast. Aerial surveys consisted of oblique photography and vertical video recordings. The aerial observations were used to locate sites for ground sampling and for validation of satellite image interpretations. Qualitative variations in sea ice and marine albedo were 
observed and mapped. The morphology of surface features was also mapped.

Submarine investigations consisted of measurements of water and ice temperature, water salinity and water depth. A transportable CTD (Conductivity-Temperature-Depth) was the primary instrument used to collect these data. A helicopter provided transportation of personnel and equipment to areas selected based on the analysis of aerial survey data. Holes were drilled through the ice and instruments were lowered into the water. Recent and ongoing measurements of offshore oceanographic conditions in this region are available in the literature. (Macdonald \& Carmack 1991).

\section{Results}

The results are discussed in order of the AVHRR satellite images acquired with a summary presented in Table 1. Albedo measurements were derived from visible (band 1) data and thermal measurements from the thermal infrared (band 4) data. The analyses reveal details regarding the thawing process of sea ice adjacent to and offshore from the delta, and the extent and circulation of warm and turbid water discharged by the Mackenzie River. Variations in fast ice, pack ice, overflows and water SST's as a function of geography and season throughout the spring and summer are shown on individual images.

\section{April 1986}

The 17 April images (Fig. 2) show surface conditions prior to observable melting activity. Fast ice along the coast, the Bathurst Polynya offshore and pack ice seaward can be seen. No overflows were observed on the fast ice. Quantitative measurements of ice albedo could not be obtained from these data due to calibration problems. General qualitative observations show ice with lower albedo offshore compared to ice adjacent to the delta. Pack ice temperatures well offshore were generally colder, less than $-20^{\circ} \mathrm{C}$, compared to fast ice temperatures near the delta. Fast ice temperatures adjacent to the delta were $-21^{\circ} \mathrm{C}$ in middle channel and to the east but slightly warmer temperatures, $-17^{\circ} \mathrm{C}$, to the west (Shallow Bay). These warmer temperatures may be related to clouds or may be indicative of actual warmer ice surface condition. Some clouds were present over part of the western side of the delta. Westward trending bands of sea smoke can be seen originating from the western side of the Bathurst Polynya.

\section{May 1986}

The 25 May image (Fig. 2) is the first scene that shows overflows at the mouths of delta distributary channels in the middle and western portions of the delta. To the east very small overfiows can be seen in the middle of the delta in Beluga Bay, but few if any in eastern regions in Kugmallit Bay (Fig. 1). Albedo measurements reveal values of $<55 \%$ for overflows and greater than $70 \%$ for ice. The thermal data reveal surface temperatures ranging from -2.2 to $-2.4^{\circ} \mathrm{C}$ in an overflow to $<-7^{\circ} \mathrm{C}$ offshore near the opening of the Bathurst Polynya. The sub-freezing temperatures of the overflows indicate that the surfaces may be frozen or that thin clouds are lowering the apparent temperature. Clouds are present over some areas that limit analyses, but a gap or thinning in the cloud layer over most of the delta permits some observations. Due to the presence of clouds, the quantitative measurements are suspect. The pack and fast ice, and polynya that separates them can be seen through the cloud cover.

\section{June 1986}

The 4 June images (Fig. 3) show that the overflows have grown considerably and now can be seen off most distributary channels. Overflows in eastern delta (Kugmallit Bay) are small compared to those in the rest of the delta. The size of the Bathurst Polynya does not appear to be significantly greater than on previous images. On the visible band data the albedos of the overflows are low, 11 to $36 \%$. The fast ice in the vicinity of the delta has a lower albedo, 36 to $77 \%$, compared to the greater than $70 \%$ values for pack ice. Due to clouds the pack ice values are probably inflated.

The thermal data reveal our first observation of overflows with above zero temperatures. The surface temperatures of overflows and ice adjacent to the delta are 0 to $2.2^{\circ} \mathrm{C}$. Seaward, fast ice temperatures decrease to $-2.4^{\circ} \mathrm{C}$ near the lead. Pack ice and polynya temperatures could not be derived due to clouds. 


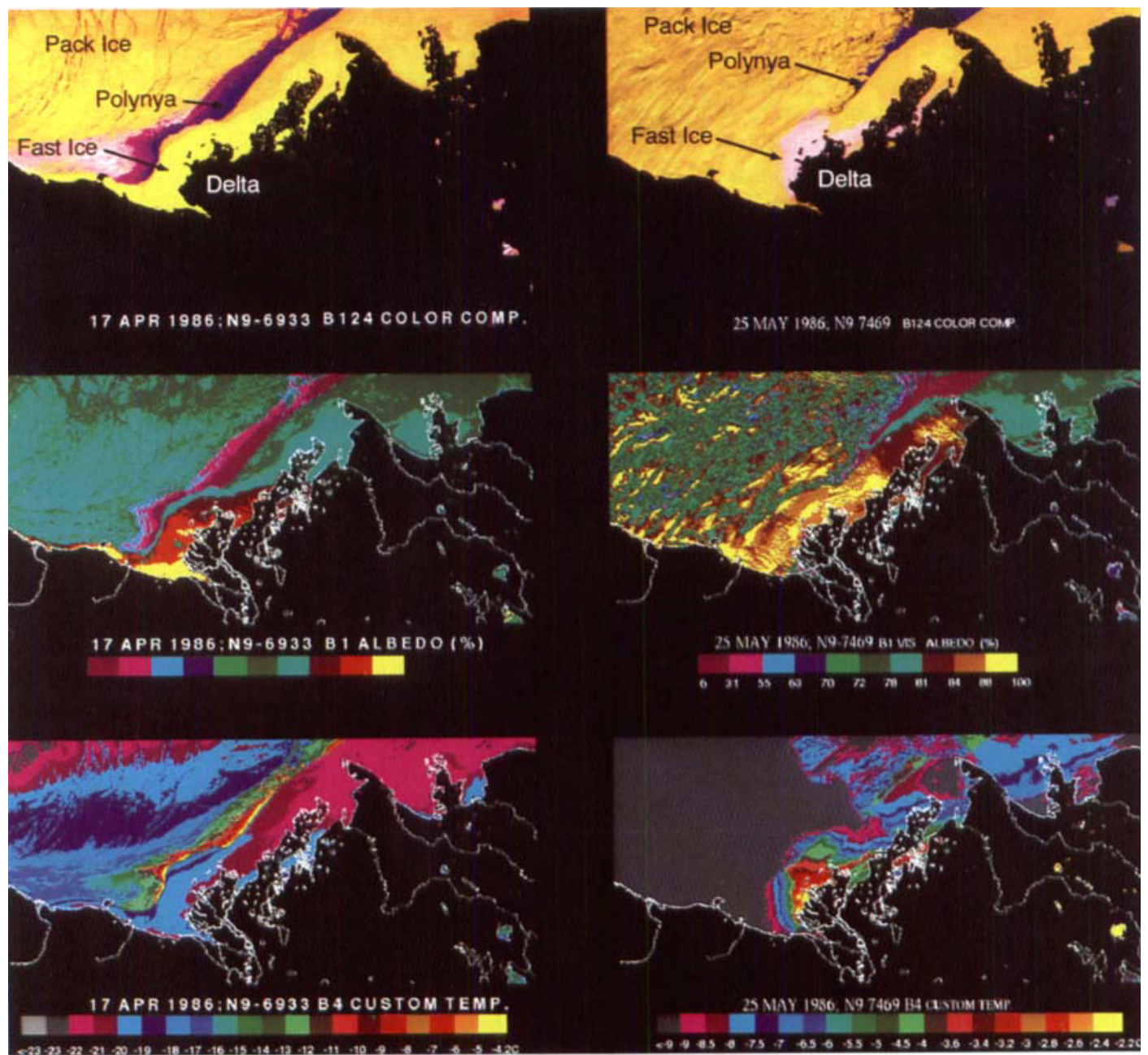

Fig. 2. AVHRR satellite images of recorded on 17 April 1986 (left column) and 25 May 1986 (right column). The top images are color composites using the visible (B1), near-infrared (B2) and thermal infrared (B4) bands of data. The center images are visible band data that have been color-coded to show albedo. The bottom images are the thermal infrared band data that have been color-coded to show temperatures.

\section{June 1986}

The 11 June images (not shown) show that the seaward extent of fast ice appears to have decreased and the polynya appears to have broadened compared to the previous image. Albedo values of the overflows, 8 to $61 \%$, are lower than fast and pack ice values which are greater than $61 \%$. Water in the polynya has the lowest albedo values, 4 to $17 \%$. These quantitative observations compare reasonably well with the previous observations even though their accuracy is suspect due to clouds. Several cloud formations are present over the delta, fast ice and pack ice affecting quantitative measurements of albedo and preventing any meaningful temperature measurements. 


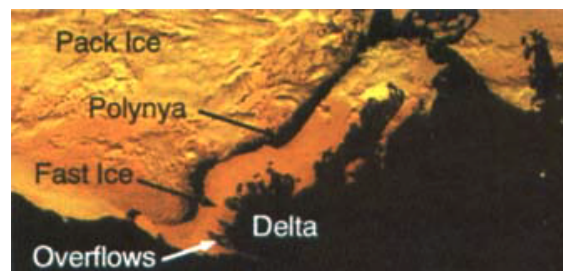

Overflows

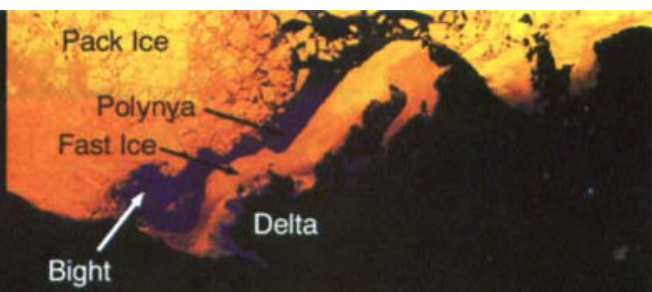

4JINE 1986. N97610 B124COLOR COMP
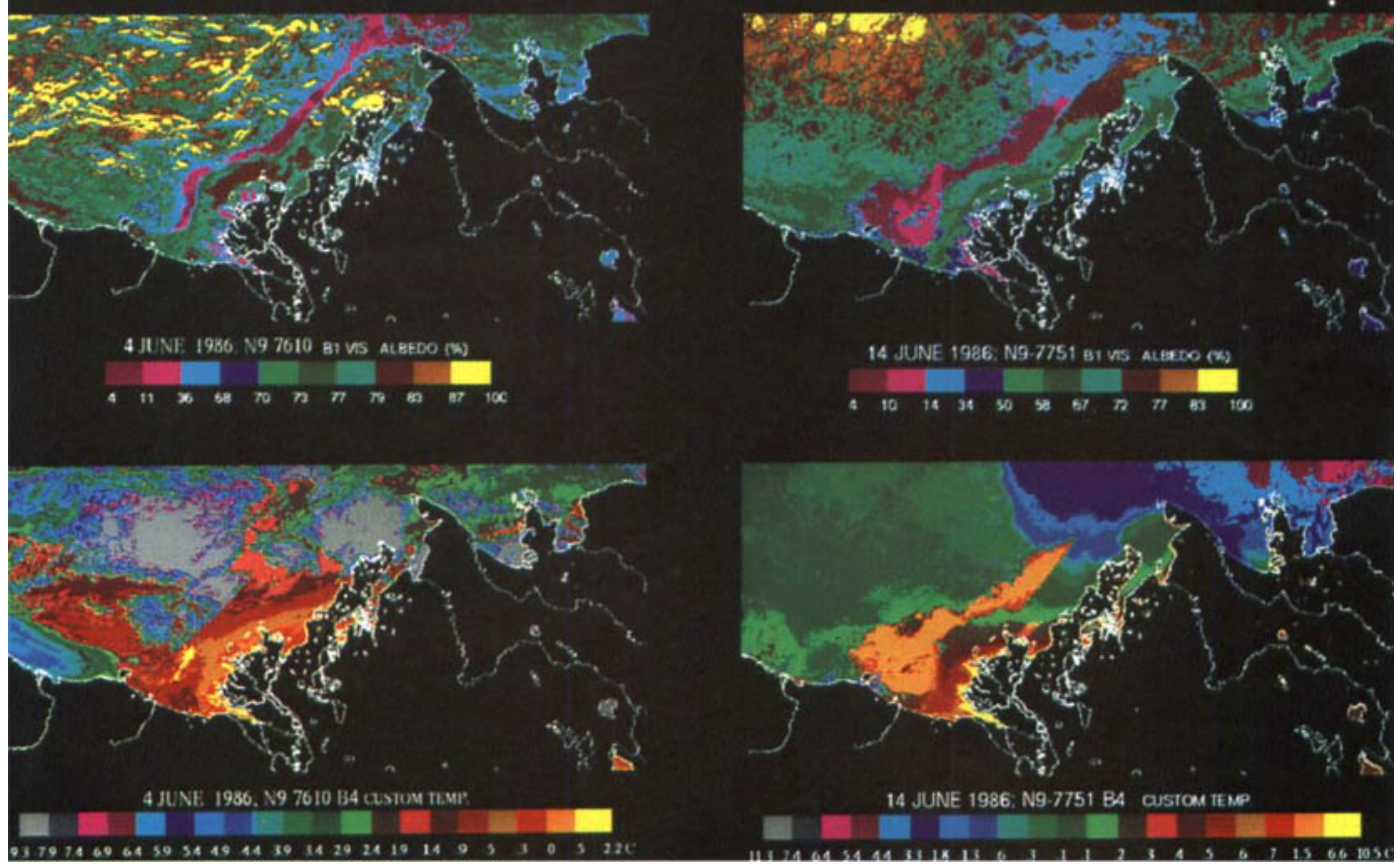

Fig. 3. AVHRR satcllite images of recorded on 4 June 1986 (left column) and 14 June 1986 (right column). The top images are color composites using the visible (B1), near-infrared (B2) and thermal infrared (B4) bands of data. The center images are the visible band data that have been color coded to show albedo. The bottom images are the thermal band data that have been color coded to show temperatures.

\section{June 1986}

The 14 June images (Fig. 3) show that fast ice along the delta thaws most rapidly in the west. The overflows are beginning to coalesce in the western and central portions of the delta and are larger in Kugmallit Bay than observed on previous images. The albedo of overflows and the immediately adjacent fast ice range from 10 to $50 \%$ with lower values close to shore. Water in the polynya has the lowest albedo, 4 to $14 \%$. Fast ice albedo ranges from 50 to $72 \%$ in the vicinity of the polynya while pack ice values are greater than $72 \%$.

The surface temperatures adjacent to the delta range from $6.6^{\circ} \mathrm{C}$ (overflows) to $0.6^{\circ} \mathrm{C}$ (surrounding ice). Fast ice next to the polynya has values of 0.4 to $0.6^{\circ} \mathrm{C}$. Water temperatures in the polynya range from 0.6 to $6.6^{\circ} \mathrm{C}$ offshore from 


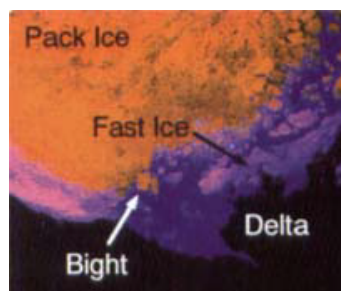

5 JULY 1986: N9-8047 B124 COLOR COMP

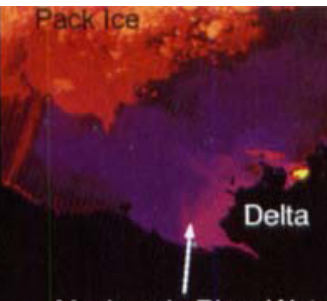

Mackenzie River Water

16 ALG 1986, N9 8640 B124 COLOR COMP
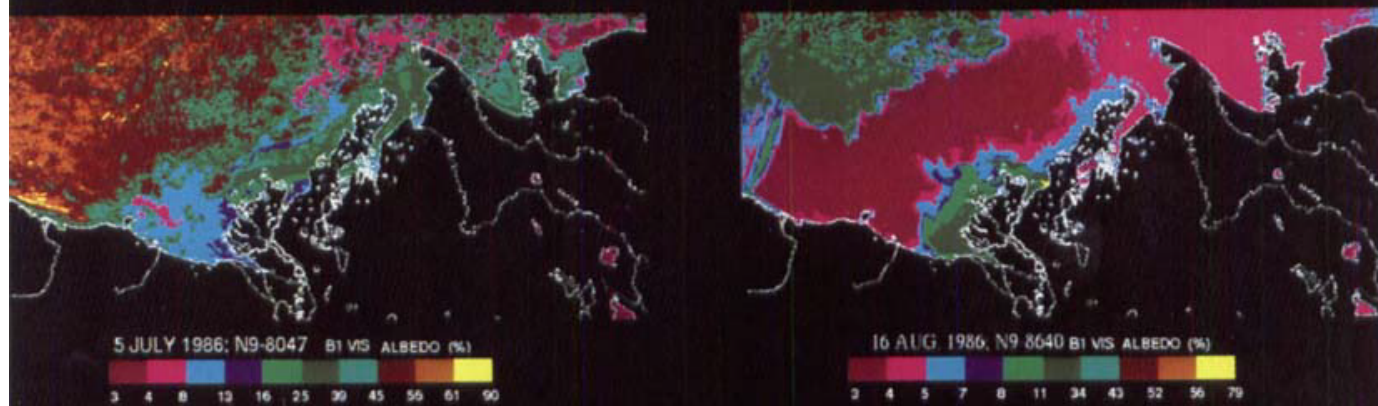

16 ALG 1986, N9 8640 BI VS ALEEDO (M)
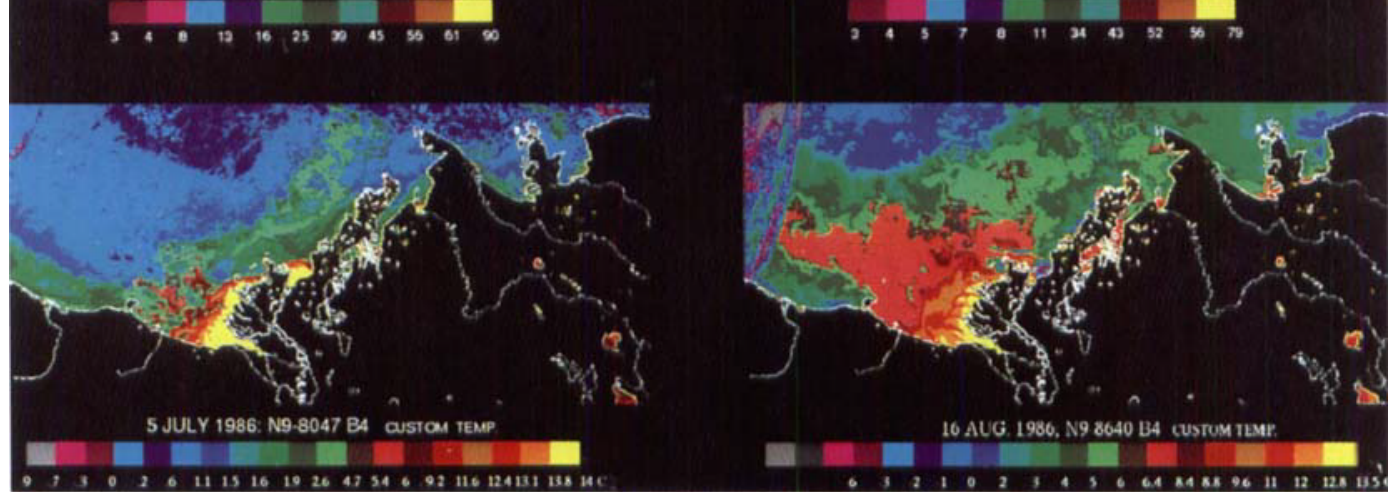

Fig. 4. AVHRR satellite images of recorded on 12 July 1986 (left column) and 16 August 1986 (right column). The top images are color composites using the visible (B1), near-infrared (B2) and thermal infrared (B4) bands of data. The center images are the visible band data that have been color-coded to show albedo. The bottom images are the thermal band data that have been color-coded to show temperatures.

the delta beyond Herschel Island. The ice edge is approximately $180 \mathrm{~km}$ offshore. Some clouds or sea smoke appear to be along the western edge of the delta, over Amundsen Gulf and well offshore over the pack ice.

\section{July}

On the 3 July images (not shown) fast ice has thawed and/or broken up offshore from the west- ern portion of the delta but can be seen to the east starting in the vicinity of Beluga Bay. In the eastern delta, Kugmallit Bay is open but fast ice extends across its entrance. The albedo of most of the water ranges from 9 to $19 \%$ with lower values adjacent to shore. Fast ice and floes have values of 30 to $50 \%$ and pack ice mostly 30 to $61 \%$. The high values near the center of the image are related to the cloud cover.

SST's near the coast range from 3.6 to $13^{\circ} \mathrm{C}$ with 
the gradient cooling seaward. Farther offshore water temperatures are 0.1 to $1.1^{\circ} \mathrm{C}$ except for some isolated warm areas where values range from 1.2 to $5.6^{\circ} \mathrm{C}$. Warm SST patterns are most extensive offshore from the western portion of the delta, seaward of Shallow Bay. Fast ice temperatures are from 0.1 to $-0.8^{\circ} \mathrm{C}$ and pack ice values are from -0.3 to $-0.8^{\circ} \mathrm{C}$. Clouds obscure the western and central portion of the area.

\section{July}

The 5 July images (Fig. 4) show that the fast ice has mostly melted or broken into floes in open water. Open water extends from the coast to the ice edge $70 \mathrm{~km}$ offshore and contains numerous floes, except to the west, where few flows can be seen. Isolated pockets of warm water in bays have begun to coalesce in the western and central delta. Several pockets or tongues of warm, coastal water can be seen advancing along shore in the middle and western regions of the delta. To the east, the open water in Kugmallit Bay is still isolated.

The albedo of the water ranges from 3 to $25 \%$ with higher values adjacent to shore or ice floes. An isolated pocket of low albedo water, 4 to $8 \%$, can be seen offshore from Herschel Island. The albedo of ice ranges from 25 to $56 \%$ with lower values ( 25 to $39 \%$ ) on floes. Values greater than $56 \%$ appear to be related to clouds.

SST's peak at $14^{\circ} \mathrm{C}$ adjacent to the coast and decrease to $1.1^{\circ} \mathrm{C}$ offshore. Ice and water temperatures near the ice edge are 0.6 to $1.1^{\circ} \mathrm{C}$ and decrease in the pack ice where clouds prevent additional measurements in most areas. Fast ice temperatures are from 1.6 to $2.6^{\circ} \mathrm{C}$. Clouds obscure features along the western and northern edges of the images.

\section{July}

The 12 July images (not shown) indicate that the pattern of ice and open water are similar to the conditions shown on the 5 July image. The albedo of water ranges from 3 to $14 \%$ with intermediate values, 8 to $11 \%$, adjacent to shore at distributary channel mouths. The area with the highest albedo, 13 to $14 \%$, is an elongated zone parallel to the central delta coast offshore from Shallow Bay and Oliver Islands. The isolated pocket of low albedo water, 4 to $8 \%$, observed on the previous image in the western and central delta has grown considerably. The albedo of ice ranges from 14 to $70 \%$ with lower values (14 to $30 \%$ ) for floes and mixed ice and water.

The SST patterns adjacent to the western and central delta coasts continue to coalesce as observed on the 5 July image, although internal temperature structures vary somewhat. These isotherms appear as an advancing front of warm water reaching about $40 \mathrm{~km}$ offshore, where the pattern starts to break up into isolated pockets of warm water. To the east, Kugmallit Bay is still isolated based on SST patterns. Coastal water SST's peak at $14^{\circ} \mathrm{C}$ adjacent to shore and decrease to $1.1^{\circ} \mathrm{C}$ offshore. Ice and water temperatures near the ice edge are 0.6 to $2.2^{\circ} \mathrm{C}$ and decrease to $-1.4^{\circ} \mathrm{C}$ in the pack ice. Some clouds are present near the center of the image obscuring some pack ice, and west of the delta and to the east in the Amundsen Gulf.

\section{August}

The 16 August images (Fig. 4) show sea ice approximately $300 \mathrm{~km}$ offshore from the delta and even farther offshore of the Alaskan coast to the west, well beyond Herschel Island. This is the first of the images analyzed that clearly shows areally extensive turbid water offshore of the delta. Few if any floes can be seen in the open water and the ice edge is highly crenulated with many floes along it.

Albedo values of water range from $11 \%$ adjacent to the coast to $3 \%$ offshore. High albedo water extends along the coast of the delta from Shallow Bay to Kugmallit Bay. The albedo of pack ice ranges from $34 \%$ near the ice edge to $52 \%$ further north.

SST's range from $13.5^{\circ} \mathrm{C}$ adjacent to shore to $2^{\circ} \mathrm{C}$ near the ice edge. Pack ice temperatures range from 2 to $-1^{\circ} \mathrm{C}$. Some clouds are located along the western and northern edge of the area with those to the north extending southward over the pack ice near the image center.

\section{Field observations}

Field measurements were acquired at nine stations offshore from the Mackenzie River Delta on 14 and 15 May 1991. The observations and measurements were made primarily of fast ice and overflows to help quantify satellite observations. Weather conditions on 14 May were calm and overcast with air temperatures from 0.5 to $1.0^{\circ} \mathrm{C}$. Data were collected at stations 1-7 on this day. 
On 15 May the weather was clear and sunny with air temperatures at $4^{\circ} \mathrm{C}$. Data were collected at stations 8 and 9 on this day.

The field measurements found the floating fast ice thickness to be approximately $2 \mathrm{~m}$, water temperatures near $0^{\circ} \mathrm{C}$ including overflows, and salinity values very nearly that of fresh water (Table $2)$. The fast ice surface was firm with very little to no snow. No melt-ponds or slush were observed and water was restricted to overflows and narrow regions along the shore where the ice had receded slightly or flooding over the shoreline had occurred.

Measurements of the water column were taken, although at two sites the water depth was too shallow (less than 0.5 meter) for the CTD. Overflows were usually measured from a hovering helicopter. At stations 8 and 9 in Shallow Bay a strong seaward current nearly prevented the retrieval of the CTD after it had been pulled under the ice edge. Also, approximately two miles north of station 9 a pressure ridge system was observed. The ridges were 2 to $5 \mathrm{~m}$ high, approximately $50 \mathrm{~m}$ long and aligned parallel to shore but eventually curving to the south along the mouth of the channel in Shallow Bay.

\section{Discussion}

The complete removal of fast ice exposing the ocean surface to the atmosphere and incoming solar radiation occurs offshore from the Mackenzie River Delta at least two weeks earlier than in surrounding areas where the influence of river discharge is minimal. However, the time sequential images show the initial melting of fast ice near the delta starts in late May, two months earlier.

The melting of ice offshore from the delta appears to be a three stage process involving flooding, insolation and the discharge of warm river water. Sea ice along the delta begins thawing in May in areas where river water overflows fast ice at the mouths of distributary channels. The overflows decrease the albedo to as little as $1 / 7$ of the initial fast ice value as seen on the satellite images (Table 3 and Fig. 2). The decrease in the albedo results in an increase in the absorption of solar radiation thus providing heat to melt sea ice. Throughout May and June the surface area of the overflows increases and thus increases the area where ice is being removed by insolation.

The albedo of fast ice in areas not affected by overflows decreased to as little as $1 / 3$ and that of pack ice to $1 / 5$ of their initial values as the season progresses. This can be seen by comparing the data from May through August (Table 3). This change is attributed to melt-ponds that form when surface snow and ice thaw (Stringer 1992). However, field observations show that meltwater ponds had not begun to form when overflows extend several kilometers offshore of the delta. The decrease in fast ice albedo due to snow melt

Table 2. Results from field measurements.

\begin{tabular}{|c|c|c|c|c|c|}
\hline $\begin{array}{l}\text { Station \# and } \\
\text { conditions }\end{array}$ & $\begin{array}{l}\text { Water } \\
\text { depth }(m)\end{array}$ & $\begin{array}{l}\text { Ice } \\
\text { thickness (m) }\end{array}$ & $\begin{array}{l}\text { Water } \\
\text { temp. }\left({ }^{\circ} \mathrm{C}\right)\end{array}$ & $\begin{array}{l}\text { Salinity } \\
\text { (ppt) }\end{array}$ & Turbidity \\
\hline \multicolumn{6}{|l|}{14 May 1991} \\
\hline 1. Bore hole & 2.6 & 2.2 & -0.01 & 0 & \\
\hline 1a. Overflow & $20 \mathrm{~cm}$ & & 0.1 & & \\
\hline 2. Bore hole & 4.8 & $2-2.5$ & $\begin{array}{c}0.0 @ 0 \text { to } \\
-0.01 @ 3 \mathrm{~m}\end{array}$ & $\begin{array}{l}0.0 @ 0 \text { to } \\
0.2 @ 3 \mathrm{~m}\end{array}$ & $\begin{array}{l}\text { Clearest water } \\
\text { obser. } 14 \text { May }\end{array}$ \\
\hline 3. Overflow & $<0.5$ & & 0.0 & & Turbid \\
\hline $\begin{array}{l}\text { 4. Hovering } \\
\text { helicopter }\end{array}$ & 1 & & 0.2 & 0 & \\
\hline 5. Bore hole & 4.2 & $2-2.5$ (est.) & $\begin{array}{c}0 @ \text { to } \\
-0.01 @ 4 \mathrm{~m}\end{array}$ & $\begin{array}{l}0.0 @ 0 \text { to } \\
0.15 @ 4 \mathrm{~m}\end{array}$ & Turbid \\
\hline $\begin{array}{l}\text { 6. Hovering } \\
\text { helicopter }\end{array}$ & $<0.5$ & & 0.2 & & Turbid \\
\hline 7. Overflow & & & 0.7 & & Turbid \\
\hline \multicolumn{6}{|l|}{15 May 1991} \\
\hline 8. Bore hole & 7 & 1.8 & $\begin{array}{l}0.24 @ 0 \text { to } \\
0.07 @ 6 \mathrm{~m}\end{array}$ & $\begin{array}{l}0.09 @ 0 \text { to } \\
0.1 @ 6 \mathrm{~m}\end{array}$ & Fairly clear \\
\hline 9. Bore hole & 8.5 & 2.5 & $\begin{array}{l}0.06 @ 0 \text { to } \\
0.02 @ 7 \mathrm{~m}\end{array}$ & $\begin{array}{l}0.05 @ 0 \text { to } \\
0.13 @ 7 \mathrm{~m}\end{array}$ & Fairly clear \\
\hline
\end{tabular}


Table 3. Summary of surface albedo from AVHRR satellite images.

\begin{tabular}{|c|c|c|c|c|}
\hline \multirow[t]{2}{*}{ Date: 1986} & \multicolumn{4}{|c|}{ Albedo \% } \\
\hline & Overflow & Sea surface & Fast ice & Pack ice \\
\hline 17 Apr. & No calibration & No calibration & No calibration & No calibration \\
\hline 25 May & $<55$ ? & Clouds & $>70 ?$ & $>70 ?$ \\
\hline 4 June & 11 to 36 & Clouds & 36 to 77 & $>70 ?$ \\
\hline 11 June & 8 to 61 ? & 4 to 17 & $>61 ?$ & $>61$ ? \\
\hline 14 June & 10 to 50 & 4 to 14 & 50 to 72 & $>72$ \\
\hline 3 July & & 9 to 19 & 30 to 50 & 30 to 61 \\
\hline 5 July & & 31025 & 25 to 39 & 25 to 56 \\
\hline 12 July & & 3 to 14 & & 14 to 70 \\
\hline 16 August & & 3 to 34 & & 34 to 52 \\
\hline
\end{tabular}

is less than that attributed to overflows and occurs as late as a month later. Thus, the overflows possess a higher rate of solar absorption at any stage of ice removal compared to regions affected only by melt-ponds. This difference is most pronounced in the early stages if ice-removal when overflows develop rapidly and extensive snow melt has not yet occurred.

As to be expected, surface temperatures increase as the season progresses. Overflow temperatures were $<-2.2^{\circ} \mathrm{C}$ in late May (Table 4). These low values may be due to cloud contamination of the received signal or to the overflow surface being frozen. Field measurements in mid-May 1991 generally found the overflows a few tenths of a degree above $0^{\circ} \mathrm{C}$ and the river water flowing beneath the ice within a few hundredths of $0^{\circ} \mathrm{C}$, but often below zero. Even though this difference is small, it appears that the overflows were adding heat while river water beneath the ice contributed little energy and may actually have been deducting heat from the ice. By 4 June the maximum surface temperatures of overflow had increased to $2.2^{\circ} \mathrm{C}$ and then to $10.5^{\circ} \mathrm{C}$ by
14 June as seen on the images (Table 4). The appearance of warm water at the delta occurs approximately a week after the water level of the Mackenzie River has peaked according to measurements made by the Water Survey of Canada at Arctic Red River 200 air-kilometers upstream. Thus, prior to early June solar radiation is probably the primary source of energy, warming the overflows and melting the ice. After this date river water appears to become the dominant contributor of heat as seen by the rise of SST's.

Between 14 June and 3 July the fast ice melted, at least in the western part of the delta, and SST's had increased significantly (Table 4). SST's doubled from approximately 7 to $14^{\circ} \mathrm{C}$, the highest measured in 1986. After early July, warm river water began to extend well offshore, melting the pack ice edge and causing it to recede significantly, as seen on the 16 August image (Fig. 4). The images show that the amount of ice melted by warm river water is much greater than that removed by solar warming of overflows.

The effect of river water on the melting of the

Table 4. Summary of surface temperatures from AVHRR satellite images.

\begin{tabular}{|c|c|c|c|c|}
\hline \multirow[t]{2}{*}{ Date: 1986} & \multicolumn{4}{|c|}{ Surface temperatures ${ }^{\circ} \mathrm{C}$} \\
\hline & Overflow & Sea surface & Fast ice & Pack ice \\
\hline 17 April & No data & No data & -17 to -19 & -20 \\
\hline 25 May & $<-2.2 ?$ & $<-3.6$ & $<-6.5$ & Clouds \\
\hline 4 June & $<2.2$ & 0.5 to $2.2 ?$ & 0.0 to -2.4 & Clouds \\
\hline 11 June & Clouds & $<0$ ? & Clouds & Clouds \\
\hline 14 June & $<10.5$ & $<6.6$ & $<0.6$ & $<-0.1$ \\
\hline 3 July & None & 0.1 to 13 & 0.1 to -0.8 & -0.3 to -0.8 \\
\hline 5 July & None & $<14$ & 1.6 to 2.6 (floes) & $<0.6$ \\
\hline 12 July & None & $<14$ & $<1.3$ (floes) & $<0.6$ \\
\hline 16 August & None & $<13.5$ & None & $<0$ \\
\hline
\end{tabular}


pack ice is especially apparent offshore from the western channels where a notch in the pack ice edge can be seen. This notch is deeper than other undulations along the ice edge and coincides with a broad portion of the fast-ice shelf, as seen on the 17 April image. The notch, readily apparent in Fig. 3, is located 'down-stream' from warm water discharged by the river.

\section{Conclusions}

Ice melts offshore from rivers earlier than it does along coasts with minimal river discharge. In the case of the Mackenzie River, fast ice is removed two weeks earlier than along surrounding coasts where river discharge is minimal. However, the ice removal process starts two months earlier.

The melting of sea ice by arctic rivers involves three processes: initial flooding, absorption of solar radiation and heat provided by warm water discharged by the river. Offshore from the Mackenzie River channels, the albedo of the water that overflows the fast ice is as much as $1 / 7$ that of sea ice values, and hence the water absorbs significantly more energy than ice-covered surfaces even after melt-ponds develop. This absorbed energy initiates the melting process offshore of river channels. In our study, the albedo values of pack ice decreased as much as $1 / 3$ between May and August. Approximately two weeks after the overflows develop, sea surface temperatures offshore from the delta begin to rise as the volume of "warm" water discharged by the river peaks and becomes the dominant source of energy that melts fast ice.

Acknowledgements. - We would like to thank the Polar Continental Shelf Project for providing accommodations and helicopter support, and the Water Survey of Canada, Inuvik, for providing ice-drilling equipment. We would also like to thank the Water Survey of Canada in Yellowknife for providing river discharge records and other very cordial assistance. T. George provided aircraft support and assistance in aerial photography and video. This project was funded by NASA grant NAGW 1835 .

\section{References}

Aagaard, K. 1984: The Beaufort Undercurrent. Pp. 47-71 in Barnes, P. W., Shell, D. M. \& Reimnitz, E. (eds.): The
Alaska Beaufort Sea: Ecosystems and Environments. San Diego, California.

Aagaard, K. \& Carmack, E. C. 1989: The Role of Sea Ice and Other Fresh Water in the Arctic Circulation. J. Geophys. Res. 94(C10), 14485-14498.

Carmack, E. C., Macdonald, R. W. \& Papadakis, J. E. 1989: Water Mass Structure and Boundaries in the Mackenzie Shelf Estuary. J. Geophys. Res. 94(C12), 18043-18055.

Kidwell, K. B. (ed.) 1991: NOAA Polar User Guide (TIROSN, NOAA 6, NOAA 7, NOAA 8, NOAA 9, NOAA 10 , NOAA 11, and NOAA 12), National Oceanic and Atmospheric Administration, National Environmental Satellite, Data, and Information Service, National climatic Data Center, Satellite Data Services Division, Princeton Executive Square, Rm. 100, Washington D.C. 20233. Pp. 3:14-3:19.

Kovacs, A. \& Mellor, M. 1974: Sea Ice Morphology. Pp. 113161 in Reed, John C. \& Sater, John E. (eds.): The Coast and Shelf of the Beaufort Sea. Arctic Institute of North America.

Macdonald, R. W., Carmack, E. C., McLaughlin, F. A., Iseki, K., Macdonald, D. M. \& O'Brien, M. C. 1989: Composition and Modification of Water Masses in the Mackenzie Shelf Estuary. J. Geophys. Res. 94(C12), 18057-18070.

Macdonald, R. W. \& Carmack, E. C. 1991: The Role of LargeScale Under-Ice Topography in Separating Estuary and Ocean on an Arctic Shelf. Atmosphere-Ocean 29(1), 37-53.

Marsh, P. \& Hey, M. 1989: The Flooding Hydrology of Mackenzie Delta Lakes near Inuvik, N. W. T., Canada. Arctic 42(I), 41-49.

Matthews, J. B. 1981: Observations of surface and bottom currents in the Beaufort Sea, Alaska. J. Geophys. Res. 86(C7), 6653-6660.

Matthews, J. B. \& Stringer, W. J. 1984: Spring brcak-up and flushing of an Arctic lagoon cstuary. J. Geophys. Res. 89(C2), 2073-2079.

Milliman, J. D. \& Meade, R. H. 1983: World-wide delivery of sediments to the oceans. J. Geol. 91, 1-21.

Morris, K., 1993: Annually recurring sea ice patterns in the nearshore region of the eastern Beaufort Sea as determined from satellite data (1974-1986). M.S. Thesis. University of Alaska Fairbanks, Vols. 1 and 2. 592 pp.

Newton, J. L. 1973: The Canadian Basin: Mean circulation and intermediate scale flow features. Ph.D. thesis, University of Washington, Seattle Washington, USA. 158 pp.

Planet, W. G. (ed.) 1988: Data Extraction and Calibration of TIROS-N/NOAA Radiometers, NOAA Tech. Memo. NESS 107 - Rev. 1, National Climatic Data Center, Satellite Data Services Division, Princeton Executive Square, Rm. 100, Washington D.C. 20233, 58 p. + appendices

UNESCO (United Nations Education, Scientific, and Cultural Organization) 1978: World water balance and water resources of the Earth, Stud. and Rep. in Hydrol. 25. Paris, France.

Stirling, I. \& Cleator, H. (eds.) 1981: Polynyas in the Canadian Arctic, Environment Canada, Occasional Paper No. 45. Canadian Wildlife Service, Edmonton, Alberta, Canada T5K2J5. 72 pp.

Water Survey of Canada, 1986: Mackenzic River at Arctic Red River Water Levels, Station 10LCO14, Yellowknife, NWT, Canada.

WMO (World Meteorological Organization) 1970: WMO SeaIce Nomenclature. WMO No. 259. TP 145, Secretariat of the World Meteorological Organization, Geneva, Switzerland. 147 pp. 